\title{
Encountering the Other: Translating South-American Myth in Cyril Dabydeen’s Born in Amazonia
}

\author{
Miguel Nenevé \\ Federal University of Rondônia, Rondônia, Brazil
}

\author{
Simone Norberto \\ Tribunal De Justiça, Porto Velho, Brazil
}

\begin{abstract}
Born in Amazonia is a book of poetry written by a Guyanese Canadian poet living in Ottawa. In order to facilitate the reading of this book by Brazilian students, we are translating the book into Portuguese. In this work we are interested in discussing the process of translating of Cyril Dabydeen’s writing on the Amazon into Portuguese, in order to serve as text to be read by Amazonian students, therefore, by readers involved in Amazonian culture. We explore the Amazonian myths present in Dabydeen's writing, so that we can offer the Amazonian Brazilian readers a plausible, pleasurable and acceptable text. We suggest that the translation into Portuguese may contribute for the students to reading a Canadian author, born in Guyana writing about the Amazon. In addition, we argue that the process of translation involves a study of Amazonian culture, history and Amazonian myth (such as Jaguar and Cobra Grande). Studies on Myth and Mythology, therefore are important for our discussion. We also consider some theories of translation, such as proposed by Susan Bassnet and Barbara Godard among others. Finally, we argue that translating Dabydeen's Born in Amazonia in Amazon region means rethinking Amazonian myths. It is, we believe, a kind of discovery of Amazon by Amazonian and by South-American promoting a new dialogue among Amazonian people and new ties among Americas. Therefore, translation is in this sense, a process of decolonization and, as Ramón Grosfoguel (2011) asserts contributes to “an inter-cultural North-South dialogue cannot be achieved without a decolonization of power relations in the modern world”.
\end{abstract}

Keywords: translation, Amazon, myth, poetry, Cyril Dabydeen

Although translatability may not be a mighty force in itself, it can trigger the attempt to counteract political power, which the various groups in such a social set-up bring to bear in order to impose their own cultural heritage upon other segments in a multicultural community (W. Iser).

I will not translate/ I will answer to myself/being authentic only (C. Dabydeen in Borges_-“Unanimous night”).

\section{Introduction}

If we begin from the above quotations, we could argue that translatability can help comprehension, making possible interactions between levels or making inroads into one another. It may get out of a different culture that is alluring, appealing and beautiful and may lead to something hybrid, perhaps not really "authentic"

Miguel Nenevé, Ph.D., professor, Department of Foreign Language and Literature, University Federal de Rondonia.

Simone Norberto, Master, Tribunal De Justiça.

Correspondence concerning this article should be addressed to Rua Santo Andre, 4152, Conceição, Porto Velho, Rondonia, Brazil. E-mail: nenevemi@gmail.com. 
as claimed Cyril Dabydeen's character. So, as a culture is not a monolithic entity, we can start asking: What is authentic? What does authenticity mean in a world that keeps moving? Perhaps the very authenticity has to do with the acceptance of hybridity, the movement to the different borders or different shores. If cultures have a genuine movement, our authenticity is to be part of it, without refusing the translation. On the other hand, there is a suggestion that being translating to Western audience may mean being appropriated according to Western interest. Is the West the authentic, or "the center-original" and the rest a translation or a copy? Is South America, the imitation, and so "un-authentic" in relation to North America? Can a translation of a text from North America in South America help erasing binary relations between the "center" (North America) and the periphery (Amazonian South America)? In this work we would like to discuss some issues of culture involved in translation into Portuguese of a work on Latin America, written in English by a Canadian poet, born in Guyana, a South-American English Speaking country. To be more precise, we want to discuss a project we have in our unviersity of Rondonia: translation of poems about the Amazon written by a Canadian author born in Guyana (part of the Amazon region).

As Brazilians living in the Amazon region, we have become interested in the poetry of Cyril Dabydeen-a Guyanese-Canadian who has written about his birth place, Guyana, the Brazil-Guyana border which is part of the great Amazon basin. Our interest in translating his work is based on Amazonian students' wish to read this author in Portuguese, as he writes about their culture, myths and reality. Thus we are interested in investigating the Amazonian myths in the poet's writing, so that we can offer the Amazonian-Brazilian readers a plausible, pleasurable and acceptable text. Understanding the presence of Brazil and Amazon in a text written by a Canadian poet who was born in South-American is a visible prerequisite for the translation. Moreover, it is necessary to understand both cultures, or rather many cultures which involve the author's environment and the Brazilian-Amazonian cultures, which are part of the poet's writing focus. As Anthony Pym (2002) states, "Translators should create a long term cooperation between cultures" (p. 200). Our purpose here, then, is to explore some issues which involve the translation of a book of poetry, written in English, interlaced with local and world mythology, into Portuguese. Dabydeen's work, although a Canadian work written in English, belongs more to the peripheral literatures of the Americas in relation to the canonical Western literature. Born in Amazonian may hint that is a work about "Amazon by an Amazonian”, as the author was born in Guyana. One may have an illusion of homogeneity in the Amazon, especially when described in English, a more globalized language. Dabydeen's work and its further translation into Portuguese could then be a response to this "single story" of the Amazon. For instance, the globalized word "Anaconda" (because the film is watched all over the world), may make some differences, disparities and contradictions in Amazon region invisible and by extension, in the Americas. Dialoguing on Dabydeen's Born in Amazonia and translating it into Portuguese, we claim, also aspire to showing the differences, contradictions in Amazon and South America that globalization may hide; it means to thinking of the heterogeneity of Amazonian culture. Translation then is not only an intercultural, but also intercultural act. The translation process may assume a "critical position relating to all centralism and universalism, refusing the notion of a transcendent center” as Antonio Sousa Ribeiro (2005) contends.

We emphasize that the English text to be translated into Portuguese was written in North America, by a Canadian poet, born in the only English-speaking country in South America, that is Guyana. For the purpose of our discussion, we would like first to introduce the author Cyril Dabydeen, his works and our translation project. 


\section{Cyril Dabydeen}

The acclaimed Caribbean writer and critic Edward Kamau Brathwaite (1995) states that the Canadian poet and fiction writer Cyril Dabydeen is "one of the most confident and accomplished voices of the Caribbean diasporas in this side of the late twentieth century" (in Born in Amazonia-book cover). More than a Caribbean voice, I would argue, Dabydeen may be also a South-American voice as he writes (or attempts to write) from the perspectives of South America and the Brazilian border. Born in Guyana, where he won the Sandbach Parker Gold Medal for his poetry (1964), before leaving for Canada, the writer keeps paying tribute to the South-American context. In Canada he is a celebrated poet and writer and has been honored by the city of Ottawa, where he teaches at the University of Ottawa, with the poet laureateship. The reader can easily perceive that the Amazon plays an important role in some of Dabydeen's writing, as he delves into the South-American myths much perceptible in his book Born in Amazonia. One can say that, unlike most of Guyanese born authors, Dabydeen also looks South, not only northward, to the Caribbean and to North America. Dabydeen's work published in the last 20 years, reveals a lot of the author's origin, his departure, his dislocation, as the author explores the feeling of being part of a Guyana and South-American diasporas.

Moreover, our interest in Cyril Dabydeen was raised because of his awareness of Brazil, South America and Latin America when writing about Canada and his native Guyana. The perception of South America as a whole and of Guyana's neighbor, Brazil seems to raise interest in Amazonian readers. When we worked with his texts in the classroom, at the University of Rondonia, for example, we could perceive a great attention of the students, because of the context of his writing. It was easy to perceive that Dabydeen's poetry was somewhat calling their attention, because it was a text about their world, about myths they already knew.

Amazonian voices and landscapes seem to appear and disappear in his poetry. Therefore, the mixture of Canadian, Guyanese and South-American beliefs in Dabydeen's poetry, provokes any reader from this part of the world to read and reread symbols and images. Even when it seems that most of the poet's origins are imaginary and invented ones, which one needs in order to survive in another country, his work invites readers to reflect on the mysterious source of imagination. In his poetry, Brazil appears as the important neighbor which, like any South-American country, is surrounded by myths, legends and mysteries. This surely appeals to stimulating projects on literature in English in the Amazon region.

Born in Amazonia, the focus of our work of translation, alludes to a worldview based on his South-American experience. At first sight the book, with its colored cover showing a picture of a supposed indigenous girl seems to be a work of travel-writing produced by someone who wants to offer an exotic image of the Amazon to the world ${ }^{1}$. As he writes about the border and the "last frontier" as Amazon is called, the idea of wildness, danger and uncertainty is also suggested. Who "controls" the frontier? Who has the authority to write about the "frontier"? Perhaps these questions are raised when reading and discussing such works.

However, when one reads Dabydeen's Born in Amazonia, one realizes that the work is more complex. In fact, it is rich in mixing mythology with contemporary themes related to the Amazon, such as Amazonian myths, ecology or environmental care, Amerindian conditions as well as colonization and exploitation of people and land. Translating such a work, therefore means more than bringing the (Canadian) center to (Amazon) periphery: It also extends the periphery (Guyana) to periphery (Brazilian Amazon) promoting, as Zila Bernd (1992) expresses, a "multiple process of transculturation” (p. 193). We could also say that our work

\footnotetext{
${ }^{1}$ In a conversation with the author, he informed me that the picture on the book cover is the photography of his daughter.
} 
as a translator should involve some "localization". As the Canadian critic and translator Louise von Flotow argues (2005), "in our increasingly globalized world, where we are relentlessly informed about and offered news and products from around the world, many texts [...] are being localized” (p. 33). We do not mean a localization in the way commercial products are translated, but in the sense that the Amazonian myths be (re)-appropriated by Amazonian people. Therefore, it was in this context that we started translating some pieces of Dabydeen's work, which motivated us to begin other translations and to have a deeper view on his work. We realized the importance of learning about South-American and Amazonian myths, so that we could understand and better translate his work. Discussing Dabydeen's work, published in North America, but focusing on Amazonian myths turned to be tricky work.

\section{The Meanings of Myth}

How can the myth of a culture be translated into another culture? Is there a "real" meaning of the Myth? Percy S. Cohen (1969), in his work "Theories of myth", contends that "(...) one of the important functions of myth is that it anchors the present in the past” (p. 349). K. K. Ruthven, referring to the mythical time, argues that one can have a synchronic and a diachronic approach:

The more familiar of the pair is the diachronic or historical approach which implies that any moment in time can be broken down into constituent elements, each of which is fully intelligible only in terms of its own individual past. (...) The synchronic approach, on the other hand, ignores the private histories of individual elements and focuses instead on the relationship between those elements at any particular moment. (Ruthven, 1976, pp. 38-39)

According to this scholar, the meaning of Myth may sometimes be hidden by the creators of myth who resists in telling everything they know or even altered something because of political or religious revisionists (Ruthven, 1997, p. 15). Ruthven clarifies that Cassirer treats myth as a primordial "symbolic form", that is, as one of those things (like language itself) which we interpose between ourselves and the outside world in order to apprehend it: To him, myth is a non-discursive, densely imagistic "language", not unlike the language of Freudian dreams, at once more archaic and vibrant than that cerebral and discursive language in which Cassirer's own book is written (Ruthven, 1976, p. 74).

What we know is that myths keep on teaching us about the steps of life, the rites of passage, and the ceremonies of initiation. The ancient images are repeated to the exhaustion in new models of society. They provide us with the symbolic episodes which every culture creates for compensation. The role of the myth is thus to turn to itself and to the archaic representation of society, in order to explain our existence. According to Mircea Eliade (1985), the search for the sources is an attempt to know the origin of objects, animals and vegetables, granting the Magic dominion and the annihilation of time. The action happens either in a superior or inferior world (p.16).

In ancient populations, according to people's costumes and behavior for hunting or harvesting, myths revealed different visions of the world, determinate by geography and habits. In hunting society, the sacralization of animals was very common. In Agricola society, however, the earth's female figure was the symbol of fecundity and fruitfulness. Joseph Campbell (1994) compares diverse social groups and identifies structural similarities in their mythologies. For this scholar, myth is the communication channel between the profane and the sacred, it mediates, educates and gives orientation to human beings in their existential road. Myth envelopes a wholeness which the consciousness cannot explain, so that it turns to the symbol which is a way of synthesizing the internal search, the desire to transcend and reach the plenitude: "The visible plan stands 
for the invisible” (p. 76). Myths fulfill our emotional, affective and intellectual needs. Even being trans-formed and translated myths keeps their essential structure. As Rina Morales (2012) contends, when speaking about Amazonian and Andean myths, they "aseguran la cohesion de cualquercomunidadhistorico-cultural...apuntam a justificar un contexto social, yaqueproporcionanconcepcionesqueexplicam el mundo real y los patronesquerigenlasrelacioneshumanas” (p. 9). It is from this perspective that myth such as the Jaguar appears and grows stronger and persuasive in the work of Dabydeen. Two important animals, the Jaguar and the Anaconda (“Cobra Grande” in Brazilian Amazon context), sometimes anthropomorphized, are part of the Amazonian myths present in Dabydeen’s poetry.

\section{The Amazon Jaguar or Onça Pintada}

Jaguars are found in the forests, swamps, dry woodland and grasslands of Central and South America. The highest population densities of Jaguars, in fact, are found in the Amazon Basin and that is the reason why the animal is so present in tales, legends, stories and myths among Amazonian people. In the Amazon region either in the trees or water (as it is one of the few felines tolerant of water), the jaguar remains, revered among the indigenous who live closely with this creature. The word "Jaguar" comes from one of the Tupi-Guarani languages, presumably the Amazonian trade language Tupinambá. The Tupian word, yaguara "beast", sometimes translated as "dog", is used for any carnivorous mammal. Sometimes Etymologists contend that the Indian word "yaguar" means "he who kills at one leap". What is important to state here, however, is that in many cultures, the feline is the symbol of power and strength and this can be seen, for example, in ceramics of the Moche culture of Northern Peru.

Moreover, the animal has also been a companion in the spiritual world. Jaguar, in Maya culture, is responsible for facilitating communication between the living and the dead and to protect the royal household. In Brazil, as in many South American countries, the jaguar is believed to give power and strength, having, for example, power over fire. It is important to mention that Jaguar is the national animal of Guyana, and is featured in its coat of arms. Dabydeen, born in Guyana is certainly surrounded by the image of Jaguar very common in the border Brazil-Guyana, near the boundaries of North and South Hemisphere. In "Hinterland", the first poem of the collection, Born in Amazonia, the poet takes the reader to his homeland, the hinterland of Guyana where god, man and animal seem to share many properties: The ground where the animal steps on is the place where man lives. Therefore at the same time that there is an approximation of man to animal, there is a dispute between them. The sovereign animal of the forest wants to conquer its space, to keep its kingdom. Endowed with a spotted coat, the Amazonian jaguar hunts and watches the forest from the trees as if connecting the animal kingdom with a superior being. When it descends, he has already made up his mind, it will take action in order to keep its royalty and be revered by other animals and men. This is also visible in the first poem of the collection Born in Amazon, by Cyrirl Dabydeen.

HINTERLAND
Looking out
from the edge
of the forest,
eyes glaring
the entire forest
looking back
emblazoning




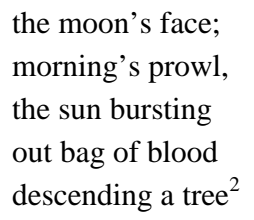

Moreover, the jaguar, which may be translated into Portuguese as "Onça Pintada" is the one who, godlike, watches over the forest and has control over the region. Further on, the poet emphasizes the importance of the myth of Jaguar: "Jaguar turns pale then red with fire". The poet combines together all these elements, in a poetical construction which is almost a narrative. Like a herald, reciting the creation, with a vibrant violence of secular pagan: “Love-calls, as they're pulled together/like magnet. They pulsate, become taut as wire. /Blood pumping, legs outstretched, apart. Humped more than/back to back. Incandescence of rosette rings/burning brightly”.

Jaguar appeals to a "sacred being" in many civilizations. For example, in some myths from South America it appears as the hero civilizer who gives the fire and the cotton weaving to the men. Among the Yanomami, the legend leads us to the first men on the earth, who were born from the union between a female Amerindian and the jaguar. This first nation people, the Yanomami Amerindians, are also present in Dabydeen's poetry: “The Yanomami Indian, too/never really down under, never in erstwhile disdain. Of the forest he has known all his life; an eye riveted to an ancient sky/as Brazil continues to shape its destiny". The destination of the people may be the end of the myth, the culture and the belief in a superior world. It is now the country that shapes the destiny rather than a sacred superior being.

Among the Mayas, also present in Dabydeen's texts, the jaguar is linked to the Goddess of the Moon and of the Earth, represented by the claws of the animal. Sometimes they epitomize the Earth in the act of devouring the sun and the twilight as the throat of the jaguar open to the Aster "that will carry/ him far/ into the lair of the moon; / growls again, / looking up/ then down once more” (p. 8). To the Aztecans jaguar was not a protector, but just a devourer, or, like an expression of the internal power of the earth making symmetry to the Eagle who represents the power of Sky, both sponsoring the great order of the warriors: "Generation of the animal-world. He knew/ all the things instinctively/ With an ear-sound, a smell, / mirroring the sky/ as he leaps high/ Looking down next at the fulsome world/ with a massive growl”.

We realize, then, that the legend of the jaguar is associated with its "continuing myth-making in South America” as one reads in the blurb of Born in Amazonia's back cover. The jaguar, generally considered to be the king of the South American rainforest, appears and reappears in the poems as if leaping from one page to

\footnotetext{
${ }^{2}$ Our translation into Portuguese.

De dentro da mata

Espiando

do canto

da floresta,

olhos faiscando-

a floresta inteira

devolve o olhar-

enaltecendo

a face da lua;

caminhada matutina,

o sol explodindo

bolsa de sangue

descendo da árvore
} 
another. One sees here again that this collection of poems mixes legends of South-American and Guyanese beliefs and experiences with the Canadian imagination. In the Amazon, the poet suggests, we live mystery and fantasy—god and humans and their fellow creatures experience a world of expectations, loss, and nostalgia.

In addition, the jaguar is sometimes a competitor to the men-something which reminds us of Jorge Luis Borges' story "La Escritura Del Dios” when a man is in a prison facing a jaguar. Furthermore, as Nenevé (2003) says in his article "Mixing South-American beliefs with Canadian experience: a study of Cyril Dabydeen texts", the Canadian poet makes an allusion to the Bible: "sloth—a hand before my eyes, I walk like Daniel into the lion's den” (p. 48). It can be said that in Dabydeen's writing, one sees an intertext with other legends, other memories, Western reminiscences. The poet reminds us that in some way his little world is part of a broader, larger and more complicated world where the beliefs and myths get together. The Amazonian Forest is a voice which will always seem to be a scream as the poem Born in Amazonia suggests (p. 35). This frightening world seems to fascinate the poet. In a letter to us Cyril Dabydeen acknowledges:

I have always been drawn to the tiger. I know that as a boy I would linger before one particular cage at the zoo; the others held no interest for one. As the years passed, this strange fascination never left me... Early in 1904, the narrator (a university professor in Laore) receives news that a new variety of tiger, a blue tiger, has been discovered in a village some miles distant from the Ganga. When he gets there, a series of events take place that must rank among Borges's finest moments as a fantasist. It is a story I have always loved. (A letter from Dabydeen to the author of this paper, May, 2007)

Therefore, addressing the myth of Jaguar means somewhat addressing a complex dialogue among cultures and myths. For some cultures, the jaguar may be the very elegant and godlike animal as well as the dangerous and devourer being. In both cases the animal fascinates human beings and is respected. Dabydeen's poem which has this wildcat as a theme transports the reader to different cultures and perceptions and to a world around us with taboos and challenges. The challenge to translate is the challenge to be able to promote the dialogue among the cultures which cultivate the myth of the jaguar.

Moreover, when we think of translating the poem from English into Portuguese, we feel invited to rethink our Brazilian folklore and legends. It is in this sense that we consider our work a "back translation". In Brazilian folklore, the jaguar embodies, among other things, the brute power. In the states of Amazon and Acre, there are legends about a fantastic jaguar-ox or a jaguar with the feet of an ox, always a couple who makes the hunter their own prey, making him climb the tree and watching him until he gets tired or sleepy and falls from there. The only way the hunter can win the feline is by killing the female, which makes the male run away. This is reflected in one poem by Dabydeen when the poet says: "this meeting of force/ and another force, / once lifted up--/ the other dead".

By reading about the jaguar and man one is reminded of the work Max e os Felinos by the Brazilian writer Moacir Scliar (2001). This book inspires Life of Pi by the Canadian Yann Martel (2002) and explores the relation of men with a panther. In both books, the protagonist has to face the jaguar or a tiger in a boat. Both man and beast dispute a small territory, where both want to reign. It is in this context that it is important to explore the myth of the Jaguar and the myth of the Amazon. This reminds us again of Mircea Eliade's (1985) suggestion as the scholar points out that by reciting and celebrating the myth, the orator lets himself or herself be impregnated by the sacred atmosphere, in which one verifies the events described by him. "This fabulous time is re-integrated and, by consequence, we become, in a sense, 'contemporary' of the evocated happenings" (Eliade, 1985, p. 40). The myth of the jaguar in an Amazonian context, for sure, influences the translator's choice when translating a poem into Portuguese from English, written by a Canadian born in Guyana. In a 
sense, there is some attempt or energy to build, as Barbara Godard (2005) contends "solidarities across heterogeneous social formation" (p. 249). The translator has sometimes to adapt the myth, so that the local students can understand, paying attention to, what Claudio Minc (2005) calls, "the role of geographical metaphors in the battle of words" (p. 1). Moreover, here in this work of translating “Amazonian” poetry, we have some proposition to offer a wider boundary of meanings, suggesting to go beyond, changing the text, but also transporting the myths to different social contexts.

Dabydeen's Born in Amazonia is peopled by gods, history, destiny, hope desires and death—developed through analogy intimately linked to an identity. In this sense we read Dabydeen's text as an Amazon cosmogony. The myth would be a mobilizing and justifying instrument, the convergent point of several themes, reflections and interrogations. Besides remembering the ancestral ones, the mythical Amazon gives us an opportunity to think about the connections among people and the possibility of a future. As the poet says "all talks, old words, dropping scales, / the dung of reality, moonshape; / pitching stars from tips/ of my fingers, blood oozing at the thighs/wetting the ground to form our roots” (Born in Amazonia, p. 12).

As we have been arguing, the act of translation also encourages to us think of the Amazon animal which takes a wider dimension and significance as the author explores the myths and beliefs mixing past and present. In Brazil, the jaguar also acquires the symbol of the Brazilian fauna, the sacred animal, the "Onça Pintada" visible in many areas of the Brazilian forest from North to South. Even the word "jaguar" or "onça" which are synonyms hold different connotations among Brazilian Amazonians. In this case, the task of the translator is also a hermeneutic task. As Carvajal (2003) says, [The translator] "has to interpret in order to understand, as translating means to understand the original in all its significant modulations” (p. 219) [my translation].

It is in this sense, that by intending to translate, one can explore further the fantastic myths, collective fantasies which are spread throughout this collection of poems. As readers living in the Amazon we ask about the relevance of these images. The transformation of a human being into a jaguar or into a serpent in order to cure and produce miracles may also mean a way of survival in many areas of Brazilian and South-American Amazon. Consequently, the transformation into other being and the sometimes abstruse symbol of jaguar must be discussed when translating the text. It is important for readers of other cultures, when they read in translation to perceive the indefinite power that the word "jaguar" conveys.

The several voices of the Indigenous people in response to stereotyped view of Brazilian Amazon, are visible in Dabydeen's work. Translating the poems in this sense, may be "re-translating”, bringing the text to the Brazilian Amazonian reader. We claim that this work also offers a pluralization and diversification of the Amazon landscape. Barbara Godard (2005), when writing about the Americas rewriting European notions, articulates this process as "repossession of America by Americans" (p. 244). Following the same logic, we could say that here we have a "repossession of Amazon by Amazonians". Discussing translation of the work, led to discussion on the political and cultural implications that such a work can generate: the integration of the "Amazonias", the extending of boundaries of its space. This has raised interests in my students and in common readers in the Amazon. The complexities of Dabydeen's writing also voices the complexity of Amazon which differ from a stereotyped "imperial" view.

In this sense, the translation could be interpreted as a counter-discourse, or a counter hegemonic effort from bellow, solidarizing with Amazonians from other countries such as Guyana and Peru among others. The Amazon we live in is still somewhat enfolded by mystery and fantasy_-gods, anthropomorphized animals and 
birds, "botos" (river dolphins), phantasmagorical creatures as "cobras grandes", or Anaconda. Humans and their fellow creatures live in a world of expectations, loss, nostalgia and anxiety. For example, the anaconda, the feathered serpent will become in a translation into Portuguese, to the Brazilian Amazonian readers, the "cobra grande".

\section{Translation of Dabydeen's “Anaconda” into the Brazilian “Cobra Grande”}

Thinking of Dabydeen's poetry and the Amazon imaginary world, we can also mention the "Anaconda" which is perhaps a more Western and globalized version of "Cobra Grande”. In its several variations, this big and powerful reptile has big and bright eyes, terrifying ones, which has won, throughout a long process, a volume from 20 to 45 meters. In its transformation process, it abandons the forest and goes to the river. From the forest, the small rivers or igarapés, the big snake has power over men: "Something merely stood back/ and watched the men/ being swallowed/ by the leviathan/ at the mouth of the river", says the poet in "Anaconda" (Dabydeen, p. 14). This reminds us of the Greek who already personified rivers into serpents, such as the Achelo river in the struggle against Hercules. The analogy with the waters and the winding course of the river justifies the symbolic association. Brazilian folklorist Câmara Cascudo (2001) refers to the monster of the water, the Black snake, of the thousand stories: "every igarapé, river or lake has its Mother and this appears only in the form of a serpent. It has no pity of humans and it does not stop its hunger. It kills, devours those it finds in its way. It turns the boat over, pulls down the swimmers, entangles the visitors to the river, it brings fear to everyone” (p. 54) (our translation). Dabydeen's poem suggests a revision of this myth in comparison to the more superficial vision of the snake. The fact is that in its different forms through which the "cobra grande" appears, it always provokes respect, fear and terror to people who live near the rivers of the Amazon. In his poem "Anaconda" (the general and global name of the snake) Dabydeen refers to the creature that swallows everything.

Anaconda
Water-hose of a reptile
Bellying our way
Through muck-inhabited
Canal
Swell each time
you swallow
donkey or pig
be barrel
and wrap
and coil
and wrap
.....

Translating "Anaconda" the global and universalized word and concept to the more local Brazilian Amazon "cobra grande” is a way of contextualizing the poem to Brazilian Amazonian readers. The globalized North-American connotation of Anaconda takes shape in a different cultural context, a South-American and Brazilian environment. To use Barbara Godard's (2005) expression "langscape and landscape remain in a dialectical tension in the social imaginary” (p. 252). 
By discussing "the cobra grande" in the Amazonian cultural context, we remember Câmara Cascudo (1954) again. This folklorist states that according to some Brazilian Amerindian beliefs, the world begins inhabited by semi-divine animals. As a fabulous animal, the snake passes through processes of enchantment and disenchantment. In addition, it goes through a constant movement along the time. The survival of this belief is deep like the Amazonian waters: The most popular mythical creations are not the regional ones but "those of universal character, ancient secular ones, sprawled over the earth's surface”, Cascudo reaffirmed. That is what happened with the great serpent which bites its own tail, representing the origin of the abysm (p. $35,123)$.

The "Cobra Grande" is an Amazon myth linked to the symbology of many geographies and traditions, such as the cultures of Central America as one sees in the Quetzalcoatl, the stuffed serpent, symbol of the rain, vegetation and later, the very Cosmos. The etymology reminds us of the water representation, which contains water. Here is the poem Dabydeen's "Quetzalcoatl, Plumed Serpent” which is part of the collection Born in Amazonia:

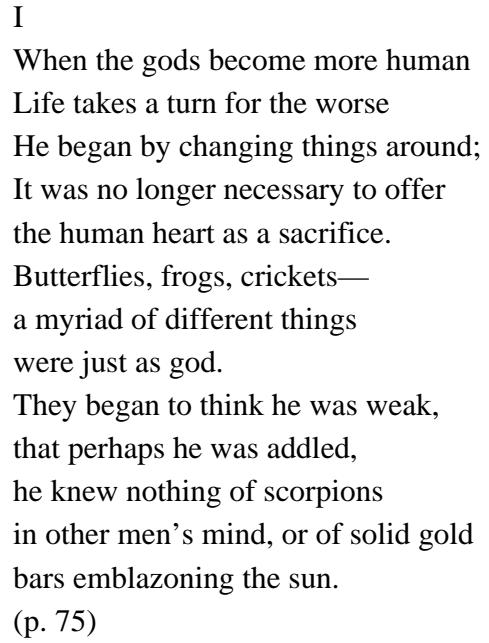

The Amazonian mythology suggests several readings and many possibilities of relating to what is known in the region. It is then necessary to translate this myth to the reality of the students in the Amazon and then convert the text into the Portuguese language. In this sense, if there is some loss in the translation into Portuguese, when the notion of the feathered serpent is transformed into the Amazonian snake (the "cobra grande" or "cobra norato"), there is also a gain, as Brazilian will see the connection of the poem with the Brazilian myth. As we have mentioned before, one may have a "repossession" of the Brazilian Amazon view. Both Quetzalcoatl and Anaconda are related to the Brazilian "cobra grande” or "cobra norato": Brazilian conceptions of the animal. As we have been arguing, they acquire new meanings when translated into Brazilian culture. For example, many Western readers may relate Anaconda to the 1997 film which starred Jennifer Lopez. That film featured the malicious gigantic South American anaconda which kills Amazonian explorers. "Anaconda" has entered into a "commercial" and sometimes colonial "trade mark". It has been used sometimes as a way to attract foreign tourists to the Amazon rivers. In our translation, when Anaconda becomes "cobra grande", there is some restoration of the mythical meaning of the snake, which is much more than "the killer" as presented in the film and in some commercial announcement. We maintain that the translation process in this case is also a means of revising myth, legends and beliefs of Brazilian Amazon, therefore, a translation back 
process.

\section{Myth, Culture and Translation}

We have been discussing here a work of translation in process in order to suggest that translating a Canadian work on Amazon also implies culture transference. We also want to sustain that cultures are universal, like myths, but they are local too and translating a work by a Canadian, born in Guyana, about South-American myth requires an extensive knowledge of the whole context of the book and the context of the target audience. In this sense, literature and local cultures need be explored, discussed and receive attention. While we think of the context where the text was produced, we must be aware that the target cultures need be considered, too. A study of translation processes, in this sense, is intended to deepen the understanding of several aspects. For example, the text was chosen because of the interest of Amazonian students. The translator's role is then to think of that audience and to offer the readers the opportunity to have a broader view of some Amazonian myths.

Susan Bassnett's writing on this subject draws our attention to the "cultural turn" in translation, the central position of culture translation and studies of translation (Bassnett \& Lefevere, 1990). Furthermore, Bassnett and Harish Trivedi explain that the word for translation in Sanskrit (anuvad) means "saying after" or giving explanation by way of repetition (Bassnett, S. \& Trivedi, H., 1999, p. 9). In this sense, our translation will be also an exploration of the Amazon myth and a way of deepening the knowledge about this place through the poetry. We understand that "saying after" implies saying from the perspective of Amazonian and South-American people: What was said in the North is "said with difference" in South-America. The translation proposes then different forms of identification offering new boundaries for the myths presented in the original texts.

As M Santiago (2009) contends, when one works with translation, one needs much more than linguistic knowledge. In order to translate, it is necessary to love the text, to read it from several perspectives. Translating, we may say, requires a great awareness of a cultural diversity, of historical marks of the peoples, and even the history of language. To study translation involves a study of cultural, economic and geographical diversity and a great knowledge of the countries, social disparities among countries and among peoples. Moreover, we are again reminded of Barbara Godard's suggestions as she (2009) proposes that translation may be considered an act of re-possession which re-writes a form of culture in order to create something new in a transformative surviving way (2009, p. 11). In this context, Godard goes farther than Seck Mbacké, quoted by Collins (2010), who argues that the translator "is obliged to follow in the footsteps of the creator. And because of that, he must do everything to understand the universe of that creator before interpreting his work” (Collins, 2010, p. 3). In our context, for example, we do not follow exactly the steps of the creator. We are interested in offering the reader the possibilities of contextualizing the foreign discourse on the Amazon. We have been suggesting that the translation of this work may give a new life to text and a new look at the Amazonian myths. Likewise, we believe, the translation can offer possibilities of reflection on cultural relations and interchange of legends and myth among people, especially people in the South-American Amazon. At the same time that by translating one offers continental ties (among Americas), we suggest a reflection on the political and cultural implications the text may entail.

Furthermore, we can say, the translation of Dabydeen's poetry may also mean a decolonization of the view of Guyana, Latin America as it stimulates discussion on issues of alterity, diversity and cultural exchanges. 
Having the Canadian work in Portuguese will help us to promote a wider dialogue between cultures, different ways of life, beliefs and other similar themes. As we know, much has been written about the Amazon, many discourses have been produced on the world's last frontier. Greedy foreign eyes observe and describe this region as exotic, chaotic (and erotic), either a green hell full of danger or a paradise where the last hope lies. Most of the time, travel-writers, novelist and journalists, reveal a classificatory view, monopolized by a discourse which homogenizes this region, putting it into a frame to be seen by the whole world. This discourse suggests that cultures do not change, that the Amazonian way of life is static and homogeneous and so, easily defined. It seems that since the travel writings such as The Sea and the Jungle by H. M Tomlinson published in 1912, Amazon Townby, Charles Wagley published for the first time in 1953, until the end of the 20th century, through works such as The Burning Season by Andrew Revkin (1990), Amazon Watershed by George Monbiot (1991), The World is Burning by Alex Shoumatoff (1990), one perceives a generalizing tendency to classify the Amazon and even to extend this classification to the whole of Brazil. "The Brazilians can see nothing here but rubber” (1989, p. 149). H. M. Tomlinson states in his work published in the beginning of the 20th century. There is no concern with the difference and diversity. Besides, frequently people are not even mentioned in the books, as if the Amazon were only a green hell, empty and ready to be occupied by colonizers, as Mary Louis Pratt argues in her work Imperial Eyes. By reading a work published in the last decade of the 20th century, one realizes that the same discourse is repeated. George Monbiot (1991), for example, in his Amazon Watershed, when referring to Porto Velho and the cities in the Amazon stated: "Porto Velho, like any large city in the Amazon, is ugly and brazen” (p. 176). There are several examples which could be quoted here. Our aim is to explore the ways we can present a counter-discourse to this "imperial view" by discussing and translating Dabydeen's work.

By reading, re-reading and translating Dabydeen's writing, one realizes that the poet is somewhat deconstructing the traditional discourse on the Amazon. Writing from the North (Canada) but being based on the South (Guyana-Brazil), the poet offers also some "solidarities across heterogeneous social formation" as Barbara Godard (2005, p. 249) expresses. As we have been claiming, this act of translating may be a back translation as the work will be translated with and to the Amazon people. We believe that when working on a project to translate a work such as this which involves myths, cultures and beliefs from different countries, one cannot lose sight of the whole aim of translation. It is necessary to be aware that it is not sufficient to decide, for example, about keeping the word "jaguar", used in Portuguese too, or opting for the more common and popular word "onça” or even "onça pintada". These are important issues to be addressed and thought about, but the overall aim of the work is much wider. It is necessary to think of the audience and the impact that the translated work will have on them. To what extent will the work be accepted as a work from the Amazon, by someone "born in Amazonia"? What effect will it bring to the audience in terms of broadening their knowledge and stimulating their curiosity on Amazonian values?

If, as the Angolese writer Agualusa (2012) says, the translator is the best reader the writer has, we really ought to read the work carefully and propose several ways of looking at the text, before giving the work to the audience. The first poem translated, was a work done together with the students: It was read several times as it was studied in the classroom. Words, expressions and idioms underwent changes throughout visions and revisions. For example, the word "hinterland" which could be "interior”, "mata adentro", "interior da mata" among other expressions was discussed. The word "jaguar" itself which may be translated as "onça”, "onça pintada”, "jaguatirica” or simply "jaguar” also raised discussions. The same could be said about "anaconda”, 
"the cobra grande”, "the sucuri”, the "cobra norato”, and so on, depending on the context. Translation has been, in this case, a collaborative work. Students help us to rethink and revise the text: As we develop the translation, we listen to students who come from Indigenous communities, native people who know about the Amazonian myth, and Amazonian people in general.

\section{Conclusion}

Amazonia as a physical, human and cultural space has elements which serve as symbolic devise, allowing its inhabitants to construct a mythical universe which respond to the physical and spiritual demands of its inhabitants. The myths present in Dabydeen's poems are related to South-American Amazon, mainly in the Brazil-Guyana border. However the myth does not obey political borders, there is the issue of language. For example, for the Macuxi Amerindian there is no sense in asking her/him if she/he is Brazilian or Guyanese. However, what makes sense is whether she/he speaks Portuguese or English. The legends, myths and beliefs are common to people in Amazonian. We argue that translating Dabydeen's poetry into Portuguese stimulates Brazilian students, professors, the academic community as well as local people to rethink of and "repossess" the legends and myth bringing more energy to research of the multiculturalism of this region. Mysteries, extraordinary animals, fantastic beings that form the magic world of Cyril Dabydeen are first translated to the local reality of students and later revised to be published to a broader community of readers. The very process of translation is a way of waking up to a big variety of legends and myths which surround us.

Additionally, the myth presented in the book Born in Amazonia cannot be inserted in a geographical site only. It suggests a border-crossing to other Amazonian countries and to the world. Moreover, the perception of identity and authenticity (if we go back to the epigraph) as Roland Walter contends, differs according to "socio-cultural, ethnic and historical context" (2003, p. 331), the same will be valid when we think of translation. We suggest that Amazonia is an entire universe inhabited by symbols, signs which provide us with a wide imaginary worlds and depending where the translation is achieved and to what kind of audience we translate, we need adapt symbols and legends. For example, the relations with the river, the forest invoke not only a variety of mysteries and imagination, but of particular vocabulary. Translating from one language into another is a way of reflecting on the several possibilities of thinking borders, frontiers and language in the Amazon. As the poet states himself, there is an exchange between the jaguar, the king of the forest, and the forest itself: The animal keeps "Looking out/ from the edge/ of the forest/ Eyes glaring--/ the entire forest/ Looking back” (1995, p. 11). This reflects what Zila Bernd (2005) reminds us: The prefix "trans” suggests "overcoming”, "going beyond" and "generating new forms of knowledge and of relation with the world" (p. 149).

Translating Dabydeen’s Born in Amazoniain Amazon region for us means rethinking Amazonian myths, a kind of discovery of Amazon by Amazonian and by South-American, but it also signifies building new dialogue among Amazonian people and new ties among Americas. Ramón Grosfoguel (2011) asserts that “an inter-cultural North-South dialogue cannot be achieved without a decolonization of power relations in the modern world. A horizontal dialogue as opposed to the vertical monologue of the West requires a transformation in global power structures” (p. 5). Translation, we argue, may help to promote a horizontal North-South dialogue.

\section{References}

Agualusa, J. E. (2012). Neeltje van Duijn in A goiabeira em flor: A tradução de elementos culturais específicosnum romance 
pós-colonial (The Guava tree in flower: The translation of specific cultural elements in a postcolonial romance). Utrecht: Universiteit Utrecht.

ALTA (American Literary Translators Association). (2003) Getting started in literary translation. The making of a literary translator. Retrieved form http://www.utdallas.edu/alta/pdf/TheMakingOfALiteraryTranslator.pdf

Bassnet, S., \& Triveddi, H. (1997). Postcolonial translation: Theory and practice. London and York: Routledge.

Bassnet, S., \& Triveddi, H. (Eds.). (1999). Post-colonial translation. Theory and practice. London and New York: Routledge.

Bassnet, S., \& Triveddi, H. (1999). Introduction. Of colonies, cannibals and vernaculars. In Bassnett and Trivedi (Eds.), Post-colonial translation. Theory and practice (pp. 1-18). London and New York: Routledge.

Bernd, Z. (1992) Bresil/Quebe: la dificile inclusion de la parole de l'autre. In Michel Peterson and Zila Bernd (Eds.), Conluences literaire: Bresil-Quebec, les bases d'une comparision (pp. 97-109). Montreal : Les editions Balzac.

Bialasiewicz, L., \& Minc, C. (2005). Old Europe, new Europe: For a geopolitics of translation. Retrieved from http://dare.uva.nl/document/359363

Collins, G. (2010). Translating Francophone Senegalese women's literature: Issues of change, power, mediation and orality (Vol. 1). Thesis submitted to the University of Warwick. 2010. Also available at http://go.warwick.ac.uk/wrap/4517

Dabydeen, C. (1995). Born in Amazonia. Oakville, ON: Mosaic Press.

Dabydeen, C. (1996). Berbice crossing and other stories. Leeds: Peepal Tree.

Dabydeen, C. (2000). My Brahmin days and other stories. Toronto: Tsar.

Dabydeen, C. (2001). Imaginary origins: Selected poems 1970-2000. Leeds: Peepal Tree.

Dabydeen, C. (2009). Unanimous night. Windsor: Black Moss Press.

Clifford, J. (1999). "Diasporas" in Routes: Travel and translation in late twentieth century. Cambridge: Harvard University Press.

Cascudo, L. da Câmara. (1954). Antologia do Folclore Brasileiro. São Paulo: Livraria Martins Editora S. A.

Cascudo, L. da Câmara. (2001). Geografia dos Mitos Brasileiros. São Paulo: Global Editoras.

Campbell, J. (1949). O Herói das Mil faces. São Paulo: Círculo do Livro.

Campbell, J. (1988). O poder do Mito. São Paulo: Editora Palas Atenas.

Cohen, P. S. (1969). Theories of myth. Man, New Series, 4(3), 337-353.

Eliade, M. (1985). Aspectos do mito. Lisboa: Edições.

Eliade, M. (2010). Mito e Realidade. São Paulo: Perpectiva.

Flotow, L. V. (2005). The strain of cultural transfer: A Brazilian critic of Canadian and other feminisms. In A. S. R. Goulart (Ed.), Perspectivas transnacionais. Belo Horizonte: ABECAN.

Godard, B. (2009). A Tradução como cultura. In M. Nenevé \& Martins G. (Eds.), Fronteiras da Tradução (Frontiers of Translation), Cultura, Identidade e Linguagem. S. Paulo: Terceira Margem.

Godard, B. (2000). Relational logics: Of linguistic and other transactions in the Americas. In A. S. R. Goulart (Ed.), Perspectivas transnacionais. Belo Horizonte: ABECAN/FALE.

Grosfoguel, R. (2011). Decolonizing post-colonial studies and paradigms of political-economy: Transmodernity, decolonial thinking, and global coloniality. Journal of Peripheral Cultural Production of the Luso-Hispanic World, 1(1), 5.

Iser, W. (2014). On translatability. Retrieved August 11, 2014, from http://www.pum.umontreal.ca/revues/surfaces/vol4/iser.ht

Joachim, S. (2010). Poética do Imaginário, Leitura do Mito. Recife: Ed. Universitária da UFPE.

Martel, Y. (2002). Life of P. Toronto: Vintage Canada.

Monbiot, G. (1991). Amazon watershed: The new environmental investigation. London: Michael Joseph.

Morales, Rina L. F. (2012). Perú, Manantial de mitos e leyendas. Lima: San Marcos.

Morisset, J. (1992). De labaye de Guanabara à la Grande Riviéredu Canada. In M. Peterson and Z. Bernd (Eds.), Confluence literaires. Brésil-Quebec, les bases d'une comparison (pp. 203-228). Montreal: les Editions Balzac.

Pym, A. (2006). Localization and the training of linguistic mediators for the Third Millenium. Retrieved from www.fut.es/ apym/on-line/cooperation.html

Pratt, M. L. (1992). Imperial eyes: Travel writing and transculturation. London and New York: Routledge.

Revkin, A. (1990). The burning season. Boston: Houghton Mifflin Company.

Ribeiro, A. S. (2005). A Tradução como metáfora da Contemporaneidade (Translation as metaphor o four time: Postcolonialism, borders and identity). Eurozine. Retrieved August. 11, 2014, from http://www.eurozine.com/articles/article_2005-07-18-ribeiro-pt.html

Ruthven, K. K. (1976). Myth. London: Methuen. 
Rutheven, K. K. (1997). O Mito. São Paulo: Perspectiva.

Shoumatoff, A. (1990). O mundo em chamas: a devastação da Amazônia e a tragédiade Chico Mendes. Tradução: Luiz Fernando Martins Esteves. São Paulo: Best Seller.

Seck, M. M. (2002). Maryrs. In H. Dia (Ed.), Poètes d'AfriqueetdesAntilles d'expression française: Anthologie (pp. 447-449). Paris: Table Ronde.

Scliar, M. (2001). Max e os felinos. Porto Alegre: L\&PM.

Souza, M. (2009). Historia da Amazonia. Manaus: Valer.

Tomlinson, H. M. (1989). The Sea \& the Jungle. Illinois: Marlboro Press.

Walter, R. (2003). Narrative identities: (Inter)cultural in-betweens in the Americas. Bern N York: Peter Lang. 